\title{
Justyna Pyzia
}

http://orcid.org/0000-0002-7407-4307

Uniwersytet Jagielloński

justyna.pyzia@gmail.com

DOI: $10.35765 /$ pk.2020.2902.010

\section{Boże klauny (u)topione w tradycji romantycznej}

\section{STRESZCZENIE}

Rdzeniem kulturowego mitu szaleństwa jest uprzywilejowanie poznawczej perspektywy szaleńca, który „krocząc przed poetą”, rozbija utrwalone konwencje myślowe, rozszerza granice poznania, odcina powiązania łączące słowa z rzeczami, jakie krępują literaturę. Dzięki dziełu Michela Foucaulta Autorka pokazuje zmiany w pojmowaniu szaleństwa i wykazuje pewne interpretacyjne przesunięcia między romantyzmem a nowoczesnością. Autorka stawia tezę, że tom Boże klauny Przemysława Dakowicza jest dewaluacją romantycznej postaci „szaleńca bożego” zastępowanego przez zdegenerowanego klauna. Dakowicz z upodobaniem sięga po biografie tych bohaterów nowoczesnego świata, którzy - angażując się bez reszty w sprawy sztuki, filozofii, religii - stanęli oko w oko z własnym szaleństwem: Wacława Niżyńskiego, żony Thomasa Stearnsa Eliota, Blaise’a Pascala, Friedricha Nietzschego, Gunthera Liebchena. Co istotne, współcześni szaleńcy nie transcendują w kierunku rzeczywistości duchowej, jak czynili to romantycy. Tom Dakowicza zostaje więc dociążony symbolicznym ciężarem nieobecności, pustki i milczenia. Celem artykułu jest ukazanie, że temat szaleństwa w Bożych klaunach rozbudowuje się na romantycznym fundamencie na zasadzie ogólnej, literackiej aluzyjności, odwołuje się w większym stopniu do modalności romantycznej niż konkretnych przykładów.

SŁOWA KLUCZE: szaleniec boży, szaleństwo, Przemysław Dakowicz, romantyzm, transgresja, zaburzenia umysłu, transcendencja, Michel Foucault, klaun, schizofrenia, nowoczesność

\section{AB STRACT}

\section{Boże klauny [God's Clowns] Drown in Romantic Tradition}

The core of the cultural myth of madness is a special treatment of the cognitive perspective of a madman, who "walks before a poet," destroys established mental conventions, widens the boundaries of cognition, and cuts connections between words and objects that restrain literature. Thanks to the work of Michel Foucault, the author shows changes in the understanding of 
madness and points out some interpretive shifts between Romanticism and modernity. The author argues that the volume Boze klauny [God's clowns] by Przemysław Dakowicz is a devaluation of the romantic figure of the "Crazy for God" into a degenerated clown. Dakowicz eagerly refers to biographies of such heroes of the modern world who entirely engaged in issues of art, philosophy, or religion - and stood eye to eye with their own madness: Vaslav Nijinsky, the wife of Thomas Stearns Eliot, Blaise Pascal, Friedrich Nietzsche, and Gunther Liebchen. Importantly, the contemporary crazy-wise do not transcend to spiritual reality, as the romantics did. Therefore, the volume by Dakowicz is weighted down with a symbolic burden of absence, emptiness, and silence. The purpose of the article is to prove that the issue of divine madness in Boze klauny is expanding from a romantic foundation based on general, literary allusiveness, and it refers more to romantic modality than to specific examples.

\section{KEYWORD S : Divine madness, Crazy for God, Przemysław Dakowicz, romanticism, transgression, mental disorders, transcendence, Michel Foucault, clown, schizophrenia, modernity}

Nowożytny prestiż szaleństwa wywieść należy z literatury romantyzmu. Rdzeniem kulturowego mitu szaleństwa jest uprzywilejowanie poznawczej perspektywy szaleńca, który „krocząc przed poetą”, rozbija utrwalone konwencje myślowe, rozszerza granice poznania, odcina powiązania łączące słowa z rzeczami, jakie krępują literaturę. Dewaluacja romantycznej postaci „szaleńca bożego”, jego transformacja w zdegenerowanego klauna - tak jednym zdaniem scharakteryzowałabym tom Boze klauny Przemysława Dakowicza. Motyw schizofrenii powraca także w jego programowych enuncjacjach:

Za Kępińskim: pojęcie schizofrenii zawdzięczamy Eugenowi Bleulerowi; schizo - rozszczepiam, rozłupuję, rozdzielam; fren - przepona, serce, umysł, wola. Objawy osiowe choroby to: 1 . autyzm, czyli odcięcie się od świata otaczającego i życie światem własnym (...). 2. rozszczepienie dezintegracja wszystkich funkcji psychicznych. Człowiek nowoczesny rozszczepione serce, rozłupany umysł, podzielona wola (Dakowicz, 2012, s. 51).

Nietzscheański błądzący człowiek, małpa Pana Boga, to kolejny, oczywisty kontekst dla omawianego tomu wierszy. „Boży klaun” przywodzi na myśl także motywikę antyczną i koncepcję „bożego igrzyska”, marionetki w rękach Boga, a więc człowieka włączonego nie tylko w sferę profanum, ale i doświadczającego sacrum. Tom dotyka bowiem następujących tematów: cisza i milczenie, (p)oszukiwanie Boga, rozmycie ludzkiej 
tożsamości, powierzchowność relacji międzyludzkich, nowy język nazywający rozczłonkowaną, rozszczepioną rzeczywistość, potrafiący zrozumieć jej szaleństwo.

Motto tomu wyjęte zostało z Wyznań św. Augustyna: „Z dnia na dzień odkładałem rozpoczęcie życia w Tobie, a nie odkładałem tego, aby co dzień w sobie samym umierać”. To dowód na zakorzenienie myślenia poety zarówno w myśli antycznej, jak i chrześcijańskiej, wskazuje na kierunek jego poetyckiego wędrowania. Śmierć to nie tylko fizyczne umieranie, ale i zrzucanie z siebie poetyckich śladów poprzedników. Umieranie w sobie nie może jednak przejść w nihilizm, w zamieranie duchowości czy moralności. Nie bez znaczenia pozostaje fakt, że tom otwiera wiersz z biblijnym nawiązaniem (Pieczara-Ślarzyńska, 2015, s. 125): „wstał Samuel i poszedł do Helego”. Jednak u Dakowicza nie kończy się ono ufnym: „Oto jestem: przecież mię wołałeś” (1 Sm 3,6-7), przeciwnie, poeta dodaje: „z ciemności/ głos:/ póki słów/ póty śmierci” ${ }^{1}$. Na wysokości „była cisza” - stwierdza poeta.

Także w esejach Dakowicz przyznawał, że współczesnemu poecie trudno jest pisać o Bogu, a jedynym sposobem dotknięcia rzeczywistości niematerialnej jest opisanie braku. Bóg objawia się więc w jego poezji jako pustka, milczenie, a paradoksalnym znakiem Jego istnienia jest Jego nieobecność (Dakowicz, 2008, s. 36 i n.). Bóg jest przecież również ciszą pomiędzy słowami, tym, czego pojęcia nie potrafią uchwycić, co się im wymyka. Proweniencja takiego myślenia to rzecz jasna tradycja judeochrześcijańska, w której pustynia wiąże się z ascezą z wyboru, ogołoceniem doznań, aby możliwe było spotkanie w ciszy - siebie i Boga. Profesor Tadeusz Sławek pisał, że „ «Niewysłowione miejsce» jest miejscem «bez ścian» - z jednej strony dochodzi do nas powiew «czystego niedoboru», z drugiej «pustego Nadmiaru»" (Sławek, 2020). To trafne rozpoznanie sytuacji współczesnego człowieka miotającego się pomiędzy metafizycznym niedoborem, niedosytem oraz życiowym nadmiarem, niemającego Domu. „Wykorzenienie rodzi bałwochwalstwo” - mówiła Simone Weil (1961, s. 194). Czy to tych czasów doczekaliśmy?

\section{Interpretacje wybranych wierszy}

Panoramę szaleńców Dakowicza otwiera obraz jednostki chorobowej, która może nie być szerzej znana czytelnikowi - chodzi o zespół Charles'a Bonneta, który dotyka głównie osoby starsze, borykające się

1 Wszystkie cytaty z tomu Boze klauny za wydaniem: Dakowicz, 2014a. 
z zaburzeniami widzenia. Nazwa schorzenia pochodzi od nazwiska szwajcarskiego prawnika, który zaobserwował specyficzne objawy u swojego dziadka. Starszy mężczyzna cierpiał na zaćmę, która w znacznym stopniu uszkodziła jego wzrok. Swoistego typu zagadką pozostaje pytanie, dlaczego osoby w podeszłym wieku, które tracą wzrok, doświadczają tych omamów wzrokowych. W wyniku problemów ze wzrokiem widzą przedmioty nieistniejące w realnym świecie. Mogą to być zarówno linie proste, figury geometryczne, jak i obrazy ludzi czy budynków. Pojawienie się halucynacji nie musi oznaczać zaburzeń umysłowych. Osoby dotknięte zespołem Charles'a Bonneta, w odróżnieniu od chorych psychicznie, szybko dają się przekonać, że widziane przedmioty nie są prawdziwe.

\title{
Zespół Bonetta
}

\author{
Stanął i stoi. Jegomość w różowym \\ pikowanym szlafroku, ćmiący fajeczkę \\ (cybuch między rzadkimi zębami, \\ gęba w szerokim uśmiechu), \\ dwudniowy zarost, na głowie \\ atłasowy beret $\mathrm{z}$ kutasikiem.
}

Monsieur Lullin wyglądał właśnie cyrulika, pogrążony w fotelu, szlafroku lilaróż i niewesołych myślach. Beret z kutasikiem zsunął się na lewą skroń.

Lullin wytrzeszcza oczy. Drugi on, choć o głowę niższy, szerszy w barach, wydatniejsze ostrogi na starczych piętach, płynie w powietrzu, trzy stopy nad ziemią i wypuszczając nosem obłoczki dymu, wykonuje głęboki ukłon.

Staruszek w fotelu drapie się

Po szorstkim policzku.

Powieki ma zaciśnięte.

Kiedy je rozwiera, Po tamtym nie ma śladu.

Mgła unosi się nad ogrodem (Dakowicz, 2018, s. 172).

Pejzaż romantyczny ze sztafażem można rzec. Dotknięty chorobą Lullin wizualizuje sobie własnego sobowtóra, zwierciadło okazuje się 
jednak pozorne. Szlafrok Lullina jest różowy, a nad ogrodem po zniknięciu „drugiego Lullina” unosi się mgła. Poprzez kreowanie elementów, nadając im aurę tajemniczości i niezwykłości, posługując się kolorystyką, grą promieni świetlnych, mgłą rozmazującą kontury malarze romantyczni ukazywali obecność wymiaru transcendentalnego. Novum było to, że sama natura zyskała rangę sacrum i to ona najlepiej wyrażała ideę religijną (Kowalczykowa, 1982, s. 45-50). Obserwowany pejzaż - zgodnie z założeniami filozoficznymi epoki - jest w istocie wewnętrznym pejzażem duszy. Unosząca się nad ogrodem mgła mówiłaby zatem o kondycji Lullina więcej, niż wydaje się po pierwszym czytaniu.

Dakowicz z upodobaniem sięga po biografie tych bohaterów nowoczesnego świata, którzy - angażując się bez reszty w sprawy sztuki, filozofii, religii - stanęli oko w oko z własnym szaleństwem. Przed oczami czytelnika paradują: jeden z najwybitniejszych tancerzy baletu XX wieku, Wacław Niżyński, tytułowy „Boży klaun”, który 19 stycznia 1919 roku swym ostatnim tańcem dokonał „zaślubin Bogu” (Niżýnski. Ostatni taniec i Nizyński. Totentanz), żona Thomasa Stearnsa Eliota (Elegia na odejście Vivien Eliot), Blaise Pascal (Nauka znikania, Ballada o znikajacym palcu), Friedrich Nietzsche z etapu naumburskiego (O cyruliku Fryderyku piosenka wesota a ogromnie przez to smutna). Pojawia się także postać niemieckiego hochsztaplera Gunthera von Hagensa Liebchena (właściwie Gunthera Liebchena), poddającego zabiegowi plastynacji ${ }^{2}$ ludzkie zwłoki (Ein Meister aus Deutschland) czy zatrutej do szaleństwa nakazami reklamy anonimowej czterdziestolatki (Poezja wspótczesna domaga się wyjścia na przepustke).

Tomik Dakowicza z 2014 roku jest więc cyklem poetyckim traktującym o osobowościach transgresyjnych, zaś poszczególne utwory do nich nawiązujące stanowią quasi-dystychy, całość tę rozbijają natomiast reminiscencje, jak ta o Guntherze Liebchenie, opętanym petryfikacją ludzkich ciał. W innych tomach Przemysława Dakowicza nie brakowało szaleńców, by wymienić tylko Emanuela Swedenborga (poemat Ćwiczony), van Gogha jako pacjenta zakładu dla nerwowo chorych w Saint-Rémy oraz Anneliese Michel, zmarłą po nieudanych egzorcyzmach w Klingenbergu nad Menem (tamże).

Wiersz poświęcony osłabionej, bliskiej śmierci, owładniętej psychozą Vivienne Haigh-Wood w istocie jest jedną $\mathrm{z}$ ważniejszych programowych wypowiedzi autora:

2 Skomplikowany proces preparacji, polegający na usunięciu z tkanek organizmu wody oraz tłuszczów i nasyceniu ich odpowiednimi polimerami, co powoduje zatrzymanie ich rozkładu, zachowany zostaje jednak ich kształt i kolor. 
Elegia na odejście Vivien Eliot

$\mathrm{Na}$ fotografiach wykonanych przez lady Morrell wiedzie żywot płynny, jakby brakowało jej ontologicznej stanowczości; cała jej postać mówi: wynosze się, wychodze, juz mnie nie ma.

Poza kadrem pościel, połacie bieli znaczone krwią miesięczną, zielonkawy puder na policzkach Toma. I jeszcze: Doris Grubonoga, Sweeney Erectus z brzytwą w dłoni. $\mathrm{Z}$ poezji co zostaje? Właśnie to: przedwieczorna chwila w domu dla psychicznie chorych, gdy, niewidziana przez nikogo, stara kobieta poprawia koc na swoich zbędnych światu kolanach.

Northumberland House, Finsbury Park, Londyn, styczeń 1947 (Dakowicz, 2018, s. 162).

Dakowicz koncentruje swoją uwagę na cienkiej linii granicznej między życiem a literaturą, jest podejrzliwy w odniesieniu do jednej z naczelnych kategorii interpretacyjnych znanych z praktyki eseistycznej Thomasa Eliota - objective correlative (Dakowicz, 2019). Osamotnienie Viv bijące z wiersza jest specyficzne, wyraża nie radykalną odrębność wobec wszystkich i wszystkiego izolującą jednostkę, lecz jest niejako trudno wyrażalną formą zestrojenia człowieka z otoczeniem, stopienia człowieka z nim aż do niewidoczności. To wręcz reifikacja.

Wspomniany już Liebchen pracował jak alchemik, szukając w manuskryptach odpowiedzi na pytanie, jak nietrwałe zamienić w trwałe, w jaki sposób śmierci dać nowe, wieczne, bezduszne życie?

nie daj się zmienić

w gnój

kąp się

w silikonie

po kawałku

po plasterku

fragmentaryczne

zmartwychwstanie (Dakowicz, 2014a, s. 27) 
- to cytat pochodzący z wiersza z podwójnym nawiązaniem, Ein Meister aus Deutschland ${ }^{3}$. Kilka lat później poemat został usunięty z tomu Boże klauny i przesunięty do Ćwiczeń duchowych ${ }^{4}$. W tej wielopoziomowej grze międzytekstowej wskażę dwa nawiązania. Pierwsze to Celanowskie oskarżenie judeochrześcijańskiej kultury, gdyż ten sam człowiek, który wypowiada w języku Goethego i Heinego zdanie: „złoto twoich włosów Małgorzato” - przeciwstawione zdaniu: ,popiół twoich włosów Sulamit przyzywa gwizdem swe psy/ Gwizdem wywleka swych Żydów każe im kopać grób w ziemi/ Nam rozkazuje teraz zagrajcie do tańca”. Piękno zostaje podważone, przypisane do języka, który nas zdradza (Celan, 2013, s. 37). Jeżeli język tworzy świat, to język obrazujący epifanię zła powinien służyć stwarzaniu pozorów, tworzyć przedmioty piękna pozornego. Bóg jest w tej poezji niewidoczny, ale pozostaje jeszcze miejsce dla rozmowy z Nim i niekiedy - jak w Psalmie czy Tenebrae - dla zwady. Bóg powracał u Paula Celana jako Nikt. Był kimś, kogo „nie ma”, a mimo to nadal jest, choć zasłonięty. Autor Róży niczyjej w każdym wierszu stara się dokonać obdukcji języka, sprawdza, gdzie pozostały blizny, gdzie odniósł on obrażenia. Zagłada skaziła język i dotknęła nie tylko ludzi, ale i samo słowo, w którym - według Zydów - mieszka Bóg. Twórczość Paula Celana staje się poszukiwaniem jakiejś drogi do innej przestrzeni, do utraconego języka, ukrytego poza słowami. Drugie nawiązanie to Różewiczowska myśl o śmierci jako anihilacji, całkowitym unicestwieniu życia, która to myśl ma wymiar konsolacyjny (Różewicz, 1991, s. 39) ${ }^{5}$. W epoce współczesnej, jak pisał Różewicz,

3 I co oczywiste, nawiązanie do próby utworzenia w Polsce zakładu preparowania zwłok. W 2005 roku Liebchen podjął próbę wykupienia w miejscowości Sieniawa Żarska w woj. lubuskim nieczynnych obiektów przemysłowych, aby na ich terenie otworzyć kolejny oddział Instytutu Plastynacji, jednak na skutek protestów motywowanych względami religijnymi projekt został odrzucony przez polskie władze. Zob. Niemiecka sprawa, „Gazeta Lubuska” 2006, nr 74.

4 Mowa o układzie tomu Dakowicz, 2018.

5 Zob. Mikołejko, 2001, s. 15: „w wierszu Der Tod ist ein Meister... szczególne znaczenie ma dwojaki sposób personifikowania śmierci: jako figury «żeńskiej» («piękna Nieznajoma») oraz «męskiej» («ein Meister»). Samobójcza śmierć Celana w wodach Sekwany to personifikacja śmierci niepozbawiającej człowieka twarzy i imienia, nie odartej z tajemnicy spotkania. Do fantazmatu Wielkiej Matki nawiązuje poeta metonimiczną frazą: «otwarte tono / rzeki / śmierci zapomnienia» (Różewicz, 2006, s. 271). Der Tod oznacza zaś zdehumanizowaną, masową śmierć w obozach zagłady. Nieprzedstawialne tabu jest tylko sugerowane przez alegorię «mistrza z Niemiec» z Celanowskiej Todesfuge (to podwójna mediatyzacja, uwypuklająca niemożność bezpośredniego przedstawiania). Jak twierdzi Jean-Luc Nancy, Zagłada jest tym wydarzeniem w historii Zachodu i jego kultury, po którym figuralna reprezentacja śmierci z perspektywy życia, pojęta jako hypotyposis, totalna i przesycona sobą «obecność uobecniona», nie jest już możliwa”. 
bogowie opuścili świat

pozostawili na nim poetów

ale źródło

wypiło usta

odjęło nam mowę (Różewicz, 2006, s. 271).

W świecie, z którego odchodzą bogowie, niemożliwym do opisania, uporządkowania i zhierarchizowania, poetów dotyka poezja żywa i w ślad za bogami emigrują i oni:
W czasie który nastał
po czasie marnym
po odejściu bogów
odchodzą poeci

- powiada Różewicz (2006, s. 271). Jedyną szansą ich ocalenia jest nadzieja istnienia, egzystencji artysty poza sztuką (Stabro, 2019).

Pustka po „bogach, którzy odeszli” (Hölderlin, a także „śmieciowy świat” Różewicza to nie miejsce zbawiennej ciszy i punkt owocnego spotkania, ale ich aksjologiczne przeciwieństwo. Świat - dom człowieka - stał się miejscem zabłąkania, o czym mówi początek wiersza Der Tod ist ein Meister aus Deutschland

- pisał Józef Ruszar (2019, s. 214).

O zabłąkaniu współczesnego człowieka mówi także wielopoziomowy poemat Dakowicza. Namysł metafizyczno-religijny spotyka się w nim z refleksją dotyczącą historii, Paul Celan i Edyta Stein „dyskutują” z medykiem - skandalistą Guntherem von Hagensem, Odnajdziemy tu symbolizującą czystą miłość Gretchen (Małgorzatę) z Fausta Johanna Wolfganga Goethego, obecną przecież i u Paula Celana (,złoto twoich włosów Małgorzato / Popiół twoich włosów Sulamit”), tutaj jednak jakże upodloną, czternastoletnią, głupią dziewuchę, która swoje nowo narodzone dziecko topi w acetonie i ofiarowuje śmierci to ciało, przekonując innych, że śmierci nie ma. Ironiczny jest komentarz podmiotu lirycznego: „autentyczny/ postmortalny/ wgląd”.

Powróćmy jednak do problematyki zamilknięcia i ciszy pomiędzy słowami. Wchodzimy tu w krąg największych tajemnic mowy, które zgłębia żydowska teologia negatywna. To teren, który penetruje także Dakowicz. Poeta zwraca się do mowy jak do Boga. Protestuje przeciwko komercjalnej tandecie, która daje nieśmiertelność (Bauman, 1998). Biorąc za przedmiot swoich wierszy konkretne historie artystów z problemami psychicznymi, 
Dakowicz stara się przedstawić konkretne objawy choroby współczesności. Chce uświadomić, że zakleszczenie w sobie prowadzi do wyjścia z siebie na zawsze (Celan, 2013).

Jak się rzekło, Ein Meister stanowi także odwołanie do Fausta. Jego współczesny odpowiednik jest jednak upiornie reprezentatywny dla zdegenerowanego społeczeństwa, przyjmującego za pewnik, że „Bóg umarł”. Popularyzator tej frazy ${ }^{6}$ Fryderyk Nietzsche jest bohaterem wiersza O cyruliku Fryderyku piosenka wesota a ogromnie przez to smutna, rozpoczętego nawiązaniem do Mickiewiczowskiej Świtezianki ${ }^{7}$. Ten młody chłopiec zadaje matce $z$ pozoru infantylne pytanie „kobieto/ gdzie jest nasz dom”, które staje się puentą tomu. Gdzie dom poezji? Gdzie schronić się mogą Boże klauny? Jak zrozumieć „dom” w świecie, nad którym nie ucichło jeszcze wołanie o śmierci Boga? Kim jest poeta dostrzegający i oceniający to szaleństwo? Jaką rolę odgrywa w takim świecie poezja? Zapytajmy za Hölderlinem: i po co poeci w czasie marnym?

Współczesna poezja podobna jest do intelektualnie powierzchownej, a emocjonalnie niedojrzałej anorektyczki, udającej przed sobą i innymi. W XIX wieku chorobą epoki była histeria, współcześnie jest nią mentalna i moralna anoreksja, choroba uderzająca w poczucie własnej wartości, zaburzająca body percept, rozmywająca poczucie tożsamości. Anoreksja pojawia się jako specyficzna reakcja na kryzys tożsamościowy w okresie adolescencji (Tan, Hope i Steward, 2003, s. 533-548), ta postać-maska poezji jest więc niezwykle wymowna. O powierzchowności poezji dotkniętej swoistym autyzmem pisał już Dakowicz w przywoływanej Nowoczesności schizofrenicznej (2012, s. 58). Programowa areferencjonalność, zatrzymanie się na granicy języka, przekonanie, że „prawda” czy „sacrum” mogą zjawiać się w literaturze wyłącznie jako obiekt zabiegów ironicznych (Dakowicz, 2014b, s. 30), a także pustosłowie i przesadna dbałość o formę są przecież grzechami naszych czasów. „Poezja współczesna domaga się wyjścia na przepustkę” - zauważa poeta, co należy rozumieć jako postulat otarcia się o świat, nabrania ciała, „mięsa”. „Twórca jest oderwany od własnego hic et nunc. To cechy dystynktywne literatury współczesnej”. Współczesny świat zgadza się na namiastki, szaleństwo zamienia w trywialną błazenadę, człowiek pozostaje na wierzchniej warstwie istnienia, charakteryzuje go „umysł niedialektyczny domagający się prostych odpowiedzi” (Dakowicz,

6 Frazy Gott ist tot jako pierwszy użył Georg Wilhelm Friedrich Hegel i odniósł te słowa do postępującej ateizacji sposobu myślenia; określił je ,jako czucie, na czym polega religia nowych czasów”, zob. Hegel, 1832, cyt. za Henrici, 2009, s. 115. Polskie tłumaczenie: Hegel, 2006, s. 18. Zob. też Kasper, 1996, s. 40.

7 Inicjalny wers: „,o to za chłopiec co za chłopiec” odsyła do Mickiewicza - „Co to za chłopiec, piękny i młody?”; zob. Mickiewicz, 1981. 
2018, s. 88), podczas gdy romantycy dzięki szaleństwu docierali do zrozumienia siebie, manifestowali możliwości poznawcze, eksplorowali pogranicza racjonalności i nieracjonalności, rzeczywistości materialnej i przeczucia innej rzeczywistości. Autor Łaczki głosi potrzebę budowania nowoczesnej świadomości, a także odnalezienia nowej formuły języka poetyckiego, który zdolny byłby do udźwignięcia prawdy o psychotycznym skrzywieniu człowieka współczesnego, języka dającego porozumienie pomiędzy czytelnikiem a autorem, języka odpowiedzialnego. Tylko wtedy komunikacja będzie pełna, gdy człowiek świadomie czyta swą historię, literaturę, gdy bez względu na dyskursy, metodologie i ideologie potrafi odnaleźć się we wspólnocie. Taką formułą jest dla Dakowicza klasycyzm postmodernistyczny.

Gest sięgnięcia do źródeł kultury europejskiej, do dzieł stanowiących świadectwo wiary w świat uporządkowany i sensowny albo tropiących i wskazujących ostatnie ślady niegdyś dostępnej całości, i wypróbowania ich w ogniu nowego języka, który przestał nazywać świat, utracił zdolność wskazywania tego, co rzeczywiste. Nałożenie siatki chaosu na kosmos tradycji. Próba odwzorowania w materiale językowym i obrazowym alogicznej struktury myślenia schizofrenicznego, wyzyskującego fragmenty dawnych konstrukcji, pochodzących sprzed kryzysu psychotycznego (Dakowicz, 2012, s. 58)

- tym właśnie miał być tom Dakowicza Boże klauny. Poezja - jako ta, która ma zdolność przekraczania ograniczeń czy to danego czasu, zastanej przestrzeni czy języka, może wychylić się ponad historię i ludzką mowę - miała stać się narzędziem w ręku łódzkiego filologa.

Przyjrzyjmy się kolejnemu wierszowi. Nauka znikania (lekcja pierwsza) to poetycki zapis „nocy ciemnej” Blaise'a Pascala, będącej źródłem jego radykalnego nawrócenia (w listopadzie 1654 roku) ${ }^{8}$. Zawiśnięcie nad tonią rzeki wskutek wypadku powozu, swoisty balans między życiem a śmiercią, natchnął Pascala do powrotu ku wierze chrześcijańskiej:

Nauka znikania (lekcja pierwsza)

Kiedy notuję moją myśl, umyka mi ona niekiedy; ale to mi przypomina moją słabość, o której zapominam co chwilę;

8 Jedna z anegdot mówi, że proweniencji „nocy Pascala” należy szukać w zdarzeniu z powozem - kareta zaprzężona w konie niemal wpadła do rzeki na moście Neuilly, dwa pierwsze konie poniosły w miejscu, gdzie nie było balustrady, i wpadły do wody. Na szczęście ich lejce się zerwały i kareta pozostała na moście, o włos od tragicznego końca. Pascal był jednym z cudem ocalałych pasażerów bądź obserwatorem całego zdarzenia. Odmienna anegdota mówi, że nie było żadnej karety, żadnych koni, inspiracją było zaś medytacyjne czytanie opisu Męki Pańskiej we własnym mieszkaniu. 
to poucza mnie tyleż co zagubiona myśl, dążę bowiem jedynie do poznania mej nicości.

Salomon de Tultie

To się stało zbyt prędko, zbyt prędko.

Albo nie stało się wcale.

Szóstka koni ciągnęła wóz. Uniosła je woda.

Na tym świecie o wszystkim decyduje przypadek, ale nic nie dzieje się bez racji.

Świeciły gwiazdy, planety wirowały, odbijając światło albo, przeciwnie, świtało i ptaki wystrzelały nad korony drzew.

Niewidzialna dłoń albo prawa fizyki zatrzymały karetę na krawędzi mostu.

Tak to zobaczymy: drewniana skrzynia na kołach wciśnięta między dwie nieskończoności.

Już w zaraniu zapadał na rodzaj niemocy, której towarzyszyły dwie dziwaczne okoliczności. Nie mógł znieść widoku ojca i matki jednocześnie, woda napawała go wstrętem, wpadał w drgawki, ślinił się, tłukąc rączkami o brzeg posłania. Sądzono, że jest zagubiony. Jakoś się wybronił. Teraz leży bez czucia w ciszy nocy lub w ciszy poranka.

Takim cię chciałem ujrzeć, frater Blasius.

Takiemu właśnie w ucho sączyć schizofreniczną kołysankę, ale ona umyka mi, umyka, gubi się w ciszy, niknie w zgiełku, rwie się i sam już nie wiem, jaką ci chciałem sączyć pieśń.

To się stało zbyt prędko, zbyt prędko.

Konie skręcały czy biegły prosto.

Dobrzy ludzie mówią: dźwięk trąb je spłoszył

lub gwiazdy świeciły zbyt jasno, a ja myślę, że one skoczyły przez wzgląd na ciebie, frater.

Ktoś chciał mieć cię tam, w dole, w ciemnym nurcie między Neuilly-sur-Seine a Courbevoie i Puteaux.

Lecz mówią także: to było na Pont Rouge i nie konie, ale ogień, ogień strawił przęsła.

Cœur Rouge. Ogień trawi twoje serce, płomień liże nasze serca albo nie, lód je skuł. 
Albo nie lód i nie ogień i nie mamy serc i nic nam nie dolega, lecz za to śpiewamy pod gwiazdami lub o świtaniu radosną pieśń schizofreników i rwie się myśl, umyka, ogień trawi narrację, gubi porządek, odpływa nasza kołysanka.

Takim cię chciałem widzieć, frater Blasius, z głową rzuconą gdzie popadnie, bez ducha, tu, pod gwiazdami, trzy sążnie od wody, która płynąc zmienia się w metaforę, między dwoma brzegami, zatrzymanego w podróży, przeniesionego w wieczność na skraju Pont de Neuilly lub na Pont Rouge, w ogniu, w nocy lub o świcie.

Mówią, że tutaj się zaczęło, żeś leżał sam Bez przytomności, na skraju dwóch Nieskończoności, że trupy koni ssało morze, że gwiazdy Bledły nad Pont de Neuilly lub Pont Rouge, A tyś przemierzał inną przestrzeń, przerażającą Przestrzeń duszy. Lecz, słyszę, śmieją się i klaszczą w dłonie, strasząc mi małą biedną psyche i już jej nie ma, nie ma: pyk! Jest noc, na skraju mostu wóz drewniany, w tym wozie próżnia, w próżni ty, śnisz sen, straszliwy sen o chorym mózgu:

po otwarciu głowy okazało się czaszka nie miała żadnej struktury prócz strzałkowej jest prawdą że miał on kiedyś spojenie które zwie się czołowym lecz długo otwarte w dzieciństwie nie mogąc się na powrót zamknąć utworzyło zgrubienie co do spojenia koronalnego nie było po nim śladu obfitość mózgu zdumiewająca a jego substancja sztywna i zagęszczona wewnątrz czaszki naprzeciwko komór mózgowych dwa odciski jakby palca w wosku

Pont de Neuilly, Paryż, listopad 1654 (Dakowicz, 2018, s. 37-38) 
Zaskakująca, lecz zgodna z historyczną prawdą - bo poezja bez odniesienia do historii jest niekompletna, nie ma sensu ${ }^{9}$ - konkluzja wiersza o odnalezieniu w mózgu Blaise’a Pascala „dwóch odcisków jakby palca w wosku" ${ }^{10}$ zwraca nas w kierunku romantycznego myślenia o szaleństwie jako boskim znaku, piętnie geniuszu ${ }^{11} \mathrm{w}$ szaleństwie świata - zbawiającym od szaleństwa schizofrenii. Wielki matematyk i filozof, dotknięty szaleństwem, ogarnięty niezrozumiałą dla innych niemocą, dręczony drgawkami i bólem, przeczuwał obecność grożącego mu palca Tego, któremu winny jest posłuszeństwo. Zjednoczenie z Bogiem niesie ze sobą potrzebę transcendencji.

Blaise Pascal, jeden z geniuszy chrześcijaństwa, będąc wybitnym matematykiem, jednocześnie był mistykiem, człowiekiem świetnie rozumiejącym napięcie między rozumem a monoteistyczną wiarą w jednego, istniejącego poza widzialnym światem Boga. Radykalna inność Boga chrześcijan i żydów powoduje, że człowiek wiary żyje w przyszłości, nadzieją przyszłości, a teraźniejszość jest stanem ważnym ze względu na czasy ostateczne. Pascal jako uczony i filozof zakorzeniał siebie społecznie i określał samego siebie w kategoriach racjonalności materialnej, według „światła przyrodzonego rozumu", jak to sformułował św. Tomasz z Akwinu. Jednocześnie posiadał silnie rozbudzoną świadomość absolutnej inności Boga, w jego umyśle nastąpiła konfrontacja dwóch nieuzgadnialnych prawomocności własnego istnienia. Rozdarcie między dwoma rzeczywistościami, charakterystyczne dla chrześcijan, miało w tym konkretnym przypadku przebieg dramatyczny. Przymus cielesnej przynależności do świata (czyli społeczeństwa i natury) oraz bycie chrześcijaninem (to znaczy człowiekiem pozaświatowym) oznaczają nieustanną konfrontację. Konieczność dystansu do świata rządzonego zasadą władzy i przemocy w imię całkowicie innej logiki, czyli religijnej zasady miłości: oto pole wewnętrznej bitwy chrześcijańskiej duszy podążającej za nauką Jezusa. Moment mistycznego zrozumienia, symbolizowany przez konkretne wydarzenie biograficzne, czyli zawiśnięcie podczas zwykłego wypadku drogowego (siedemnastowieczny entourage nie zmienia istoty wydarzenia), został przywołany jako przykład „chrześcijańskiego obłędu” rozumianego właśnie jako przerażające, bo nieuzgadnialne, napięcie duszy.

9 Wiersze z tomu Boże klauny posiadają adnotacje o miejscu i czasie powstania. Są kolejnymi narracjami. Na fakt ten uwagę zwróciła już Pieczara-Ślarzyńska, 2015, s. 127.

10 Fragment sprawozdania z autopsji Blaise’a Pascala. Zob. Muir, 1996.

11 Maria Podraza-Kwiatkowska zwracała uwagę na fakt, że temat geniuszu był często podejmowany pod koniec XIX wieku, także przez filozofów, by wymienić największych - Schopenhauera i Nietzschego. Jak stwierdza pani profesor, supremacja jednostki genialnej przyczyniła się ogromnie do poprawienia pozycji artysty, umieszczanego przecież zawsze w niedalekim sąsiedztwie geniusza, zob. Podraza-Kwiatkowska, 1969, s. 3. 
Niektóre z przedstawionych w Bozych klaunach portretów szaleńców ukazują wypaczenie romantycznego wzorca, karłowatość współczesnych ich realizacji, to szaleńcy à rebours: jegomoście w różowych szlafrokach, czterdziestolatki w minispódniczkach plujące paznokciami, współczesne wersje Narcyzów pracujących nad miarę w firmie konsultingowej, byle „wyrobić normę”, osiągnąć narzucony target. Przemysław Dakowicz, tak jak romantycy, żąda od poezji o wiele więcej, między innymi oddawania sprawiedliwości widzialnemu światu, dawania świadectwa, czystej kreacji, poszukiwania tropów zbiegłych bogów. Powraca tu wizja poezji, która użycza swojego głosu, a umniejsza swoje pragnienia: wiersz nie jako emanacja ego poety, ale głos w nieprzerwanej rozmowie pokoleń. Postać poety jako medium przeszłości pojawiła się już w tomie Łaczka (2014): „Przygarniam was, przygarniam bezimienni. Niech was ogrzeje oddech żywego. Oddaję wam mój głos. Wejdźcie mi w krew, Cienie” (Dakowicz, 2013) czy w Ćwiczeniach duchownych:

mówić za niego

własnym głosem, bo przecież ktoś

mówić musi. Inaczej wszyscy będziemy

martwi (Dakowicz, 2018, s. 194).

Odbudowa, przypominanie tego, co legło w gruzach i uległo zapomnieniu - to dziś najważniejsza misja poezji, uważa Dakowicz. Twórca chce dla współczesnego człowieka wyroku lepszego niż ten wypowiedziany w Nocy ducha i dezintegracji pozytywnej:

\author{
obciągnięty skórą \\ wydany pięciu zmysłom \\ aż do końca \\ na wierzchu (Dakowicz, 2018, s. 171).
}

Rozdarty między noc ducha mistyków i wiedzę nowoczesnej psychiatrii ${ }^{12}$, między mistyczną ciemność a naukę Vigilius odnajduje się bezbronnie, bezlitośnie zamknięty w tym, co materialne i zewnętrzne. Tego typu podejście do poezji i jej roli zauważalne było już we wspomnianej Łaczce. Vigilius jest postacią, którą czytelnicy Dakowicza znają z tego tomu. Ten strażnik prawdy wyzbywa się złudzeń co do możliwości poznania tego, co głębokie. Nie doświadcza on mistycznych spotkań, ale nie popada też w patologiczne stany nerwicowe. Nie odnajdziemy tu pragnienia

12 Dezintegracja pozytywna, rozumiana jako etap dojrzewania, rozwoju człowieka, to pojęcie stworzone przez Kazimierza Dąbrowskiego. 
ciemności, która nie jest płaskością, szaleństwa, które daje poczucie istnienia, głębi pozwalającej wstąpić pod powierzchnię. Czy wbrew deklarowanemu wyzbyciu się masek i przebrań nie ma jednak w tych frazach manieryczności? Dakowicz tak obawia się myślowego prostactwa, piętnuje mechaniczne nawracanie do romantycznego modelu literatury, historiozoficznej nekrofili, a przecież świadom tego wykonuje w swej poezji właśnie to, co zdiagnozował!

\section{Romantyczne antecedencje}

Romantyczny szaleniec z kolei czuł „całym sobą”. Szaleństwo było dla niego szansą rozszerzenia dyspozycji poznawczych człowieka. Przypomnijmy ten podstawowy dla polskiego romantyzmu model ${ }^{13}$ : w Romantyczności Adam Mickiewicz zburzył ograniczenia oświeceniowej epistemologii, zrewolucjonizował myślenie o wartości choroby umysłu. Mickiewiczowska Karusia to pierwszy wczesnoromantyczny portret osoby szalonej. Naturalnie sam autor nie nazywa dziewczyny obłąkaną czy szaloną ${ }^{14}$, jednak jej określone zachowania, zniekształcenie realnego świata w jej słowach, zerwanie kontaktu z rzeczywistością, brak reakcji na słowa otaczających ją ludzi pozwalają wysunąć tezę o jej anormalności. Na co dzień dziewczyna jest wioskowym odmieńcem. Jej zaburzone zachowanie wywołuje agresję „złych ludzi”, ale jej stan ma cechy „świętego szaleństwa”, którego źródłem jest widzenie ekstatyczne („oczyma duszy”). To wiara ludu, sakralny obraz świata, pozwala odsłonić w kondycji Karusi sakralną podstawę i nakazuje potraktować jej szalone zachowanie i wyznanie jako zdarzenie nadnaturalne - „cud”. Rozpoznany cud rytualizuje zachowanie gromady i reintegruje ludową wspólnotę. Siłą miłości i cierpienia jest w stanie wzbudzić litość w krainie umarłych i otrzymać dar nadnaturalnego widzenia (Dopart, 2000, s. 285). Jej widzenie na opak jest znakiem, że znalazła się w obliczu tajemnicy świata zmarłych.

Zatem w kontekście ballady martwe prawdy, te dostępne Starcowi, mają znaczenie poznawcze tylko w określonym zakresie, dopiero bowiem „prawdy żywe” przynoszą ważkie rozstrzygnięcia światopoglądowe. Zauważalną waloryzację odmieńców w XIX wieku łączyć trzeba

13 Pisałam na ten temat w: Pyzia, 2018, s. 25 i n.

14 Sytuacja Karusi, rozpaczającej za utraconym kochankiem, co oczywiste, nawiązuje do preromantycznej dumy. Mickiewicz, odrzucając jednak czułostkową tkliwość, przemawia do poznawczej ciekawości czytelnika. Mam na myśli dumę grozy o charakterze sensacyjno-upiorowym, w duchu preromantycznego gotycyzmu. Duma w tej wersji przekształciła się w romantyczną balladę pt. Duma o Wactawie Rzewuskim J. Słowackiego (1833). 
z poszukiwaniem odwiecznych prawd na antypodach rozumu ${ }^{15}$. Szaleniec jako jednostka nawiedzona, która znalazła się w przestrzeni sacrum, wstąpiła w sferę prawd ostatecznych, co jest porównywalne z mistycznym wtajemniczeniem - oto pierwsza grupa realizacji tematu szaleństwa. Innych modalności nie będę tu przywoływać, odsyłam zainteresowanych do swojego poprzedniego artykułu.

Szaleństwo stanie się oskarżeniem epoki, pisarze zwrócą uwagę nie tyle na ułomności organizmu ludzkiego, ile na patologię sytuacji ogólnej i ujawnią się na tym tle szczególnie mocno konflikty rozgrywające się w duszy bohatera, odsłaniające jego tajemnicze głębie (Kowalczykowa, 1978, s. 13).

Ta refleksja ma jednak dużo wcześniejszą proweniencję, to już Chateaubriand stwierdził, że do szaleństwa dochodzą umysły wrażliwe, obłęd jest znakiem bogactwa wewnętrznego i tkwi w indywidualnościach wybijających się ponad przeciętność (zob. Chateaubriand, 1982; 1991). Szaleństwo jako transgresja, przekraczanie swojej duchowości, stwarzanie swojego „,ja”, szlachetna odmienność jednostki wrażliwej wyraźnie przeciwstawiająca ją - jej indywidualność - światu, jest jedną z tych modalności romantycznego szaleństwa, co ważne, najbliższą modernizmowi, która najbliższa jest też Dakowiczowi.

Bo na drogach Pańskich ciemno,

I często jest krwią zbryzgana

Ta ciemna i nocna droga,

Krwią szaleńców roztrąconych o Boga (Słowacki, 1983, s. 72).

Romantyzm niezaprzeczalnie zmienił patrzenie na szaleństwo, od pogardy względem szaleńców i ich marginalizacji w społeczeństwie, w kierunku tłumaczenia platońskiego, jakim jest uznanie szaleństwa za cenny dar bogów, nie zaś poniżenie rozumu. Foucault - już w oderwaniu od problematyki religijnej - wykroczył poza aspekty historii społecznej i instytucjonalnej, wskazując na projekt „pokusy romantycznego irracjonalizmu” (Gutting, 1989, s. 265). Filozof sugerował, jakoby szaleństwo, uwikłane w relacje społeczne i ekonomiczne, było w rzeczywistości społeczną alienacją, podkreślał znaczenie i ciągłą obecność szaleństwa w naszej kulturze jako tego, co wyznacza granicę pomiędzy tym Samym a Innym (Obcym) i co jednocześnie daje możliwość określenia, czym ta kultura jest, jaka jest jej tożsamość, w jaki sposób ma poszukiwać swojej własnej historii

15 Współcześnie temat jest eksplorowany, by wymienić tylko wznawianą książkę Lombroso, 2015. 
(Kapusta, 2011, s. 77). Wolnemu i posiadającemu swój język szaleństwu prawo głosu odebrał Klasycyzm przez „Wielkie Zamknięcie” ludzi nierozumnych/jednostek aspołecznych). Następnie, pod koniec XVIII wieku i na początku wieku XIX, szaleńcy zostają uwolnieni z łańcuchów przez Henry'ego Scotta Tuke'a ${ }^{16}$ i Philippe'a Pinela, tylko po to - jak powiada Michel Foucault - aby jeszcze skuteczniej zostać uwięzionymi w więzieniu moralności, szaleństwo jest bowiem uznawane za nieustanne zagrożenie moralnego porządku - za moralny upadek. W ostatnich fragmentach Historii szaleństwa autor zapowiadał jednak powrót tragedii szaleństwa w literaturze, mającej uwolnić prawdę o człowieku i pokazać jego konfrontację z własnym przeznaczeniem.

Należy zwrócić uwagę, że owa konfrontacja dokonywała się już wyraźnie w XIX stuleciu, czego dowody znajdziemy między innymi w polskiej literaturze romantycznej. Cezura romantyzmu jako czasu odsłonięcia się szaleńców w przestrzeni kulturowej wydaje się jednak jak najbardziej trafna. W „wieku klasycznym” wykluczenie obłąkanego/szalonego nie zostawiało możliwości porozumienia między rozumem i szaleństwem. Pooświeceniowe szaleństwo było „nierozumem”, nie posiadało języka innego niż język rozumu, w którym mogłoby rozmawiać. W XIX wieku pojawia się możliwość rzeczywistej komunikacji między rozumem i szaleństwem. Szaleństwo na nowo odnajduje swój język w poezji Hölderlina i Gérarda de Nervala. Język ten wypowiada „utajoną prawdę o człowieku” (Foucault, 1987, s. 465), poezja to bowiem tajemniczy głos wnętrza, a spoza jej wersów wyziera prawda. Uwidacznia się w tym przekonaniu Foucaultowskie pokrewieństwo z Martinem Heideggerem, który twierdził, że nie w filozofii (metafizyce), a w poezji należy szukać myślenia istotnego. Wydaje się, że szalony poeta posiada mowę stanowiącą „domostwo bycia” (Heidegger, 1995, s. 137 i n.).

Dakowicz szalonym poetą nie jest, swoimi wierszami usiłuje poruszać w czytelniku wyłącznie ponowoczesne struny, gdyż sądzi, że romantycznych w nim już nie ma:

Pamiętasz Wyspiańskiego? W „Weselu” Stańczyk mówi do Dziennikarza: „ale Świętości nie szargać, bo trza, żeby święte były”. I ja też - trochę innym sposobem, innymi środkami - staram się mówić to samo, właśnie po to napisałem Teorię wiersza polskiego. Ale kiedy to mówię, to jakiś chochlik, jakiś taki wewnętrzny Stańczyk, przedrzeźnia mnie i obśmiewa, powtarzając: „nie bądź taki solenny, nie nadymaj się”. A ja czuję, że on ma rację, że do współczesności nie można przemawiać językiem wyjętym z dzieł romantyzmu, że nie można czytelnika okładać mesjanizmem, winkelriedyzmem, wallenrodyzmem, czy czym tam jeszcze. Więc muszę

16 Tenże źródeł szaleństwa dopatrywał się w życiu nowoczesnego społeczeństwa. 
główkować, jak bronić tego, co nazwałeś „świętością słowa”, ale bronić skutecznie, tzn. tak, by trafiać do odbiorcy współczesnego i poruszać w nim jakieś nowoczesne lub ponowoczesne struny, bo strun romantycznych już dawno w nim nie ma, a to znaczy, że nie da się ich poruszyć. (...) Zupełnie nie interesuje mnie poezja atramentu, interesuje mnie wyłącznie to, co poeta zapisuje własną krwią. W nosie mam wszelkie sztuczki literackie, jeśli służą tylko sztuczkom, jeśli ich podstawową funkcją jest udowodnić, że piszący to jednostka inteligentna i błyskotliwa. Wśród poetów zbyt wielu jest błyskotliwców, wytwórców świecidełek, o których za dziesięć, dwadzieścia lat nikt nie będzie pamiętał - choćby nawet otrzymali za nie wszystkie polskie nagrody literackie (Robert, 2020).

Obsesja poezji zapisywanej własną krwią wypada sztucznie. Obawiając się twórców błyszczących sztuczkami literackimi i błyskotliwością, poeta sam stał się tych świecidełek wytwórcą. „W wierszach Dakowicza ważne są pomysły lingwistyczne, brzmienia, rytmy, echa, «cytaty-cykady», centony, kompozycje samoistne złożone z tekstów kultury” (Ligęza, 2014), szafowanie kontekstami, intertekstami, ironiczne przekształcenie. Boże klauny były poszukiwaniem odpowiedzi na pytanie, jak możliwa jest kultura w cywilizacji postchrześcijańskiej, świadomie zrywającej ze swoimi źródłami. Dakowicz, świadomy faktu, że poeci nie zadają już ważnych pytań, a istota poezji mocno się zdewaluowała, stawia je wręcz natrętnie, ale odpowiedzi się rozmywają. Wiersze zdają się nazbyt manieryczne, za łatwo zdradzają całe zaplecze duchowe i intelektualne autora, a wpisana weń poetyka świadectwa sprawia, że wersy wybrzmiewaja przez to bardziej grobowo, ostatecznie. Współcześni szaleńcy nie transcendują w kierunku rzeczywistości duchowej, jak czynili to romantycy. Tom zostaje więc dociążony symbolicznym ciężarem nieobecności, pustki i milczenia.

\section{Konkluzje}

Czy romantyczne hasła potrzeby autokreacji i samodzielnego nadawania sensu światu (Janoszka, Kalarus, 2013, s. 9) mogą stać się swoistym panaceum na ponowoczesny kryzys podmiotowości? Krytycy zgodnie twierdzą, że współczesność wciąż stać na lirykę większą niż tę zasuszoną w likwidatorskim geście poezję znudzonych nihilistów (Tarczyńska, 2017). Przemysław Dakowicz wierzy, że „naczelne zadanie poezji jest doskonale zbieżne z funkcją psychoterapii egzystencjalnej” (Dakowicz, 2012, s. 59). Poezja jest poszukiwaniem sensu zdolnego leczyć schizofreniczną osobowość współczesnego człowieka. Poezja jako farmakon ocalający przed rozpaczą, unicestwieniem i nihilizmem - pobrzmiewa w tym 
„programie” romantyczna wizja twórczości poetyckiej, która budowała tożsamość Polaków, pozwalała wspólnocie na trwanie. Była jej pamięcią i siłą do dalszego istnienia ${ }^{17}$. Współcześnie nie możemy tego zdania wypowiedzieć. Zmieniła się sytuacja polityczna, historyczna, socjologiczna etc. Do tradycji romantycznej autor $A f a z j i$ sięga więc na poziomie formy. W wierszu poświęconym Blaise'owi Pascalowi (Ballada o znikającym palcu) wykorzystuje konwencję ballady romantycznej, przywołując także preromantycznego Króla elfów Johanna Wolfganga Goethego zarówno na płaszczyźnie rytmicznej, wersyfikacyjnej, brzmieniowej, jak i w warstwie treściowej: motyw cierpiącego na tajemniczą chorobę syna, którego próbuje ratować ojciec (Nowak, 2017). Trzeba jednak przyznać, że jest to raczej efekciarski gest poszczycenia się elokwencją i umiejętnościami formalnymi aniżeli dogłębne zrozumienie spuścizny romantycznej.

Gama inspiracji autorskich jest zresztą niezmiernie szeroka, Dakowicz w wywiadach chętnie wymienia Adama Mickiewicza, Juliusza Słowackiego, Cypriana Norwida czy Antoniego Malczewskiego jako tych, których dzieła nadbudowane są nad jego wierszami, równocześnie nieustannie podkreśla, że zachowuje dystans wobec każdej tradycji, z której czerpie. Czy jego ironiczna gra nie przechodzi już w kontestację? Temat szaleństwa w tej poezji rozbudowuje się na romantycznym fundamencie na zasadzie ogólnej, literackiej aluzyjności, odwołuje się w większym stopniu do modalności romantycznej niż konkretnych przykładów. Opierając się na modernistycznych doświadczeniach kulturalnych, gra z romantycznym dziedzictwem. Dakowicz wpisuje się w dokonujące się od jakiegoś czasu zmiany zainteresowań badawczych - odchodzi się od restrykcyjnie pojmowanej autonomiczności tekstów na rzecz dowartościowania kontekstów i otwartej, choć niejednoznacznej podmiotowości ${ }^{18}$. Dziedzictwo romantyczne ocenia jako „dawne, spetryfikowane struktury semantyczne” (Dakowicz, 2014b, s. 24), w które należy tchnąć nowe życie.

Dakowicz podąża niewątpliwie drogą Marii Janion, drogą adaptacji kultury przeszłości do współczesnych założeń zasad recepcji zjawisk kultury, jak ją nazywa Bogusław Dopart (2018, s. 66-87). Nie sposób zgodzić się z Elżbietą Morawiec, nazywającą Dakowicza obrońcą paradygmatu romantycznego (Morawiec, 2015). Łódzkiego poetę i badacza literatury romantyzmu należy wpisać raczej w szereg osób modernizujących

17 Myśli Mochnackiego stanowią dla Dakowicza istotną inspirację w tym myśleniu, szczególnie jego koncepcja narodu. Zob. Mochnacki, 1984.

18 Refleksja nad dziedzictwem romantycznym wciąż jest podejmowana przez historyków literatury, świadczą o tym kolejne konferencje i publikacje naukowe. Przywołam tylko kilka, których nie wspominałam w przypisach: komparatystyczna praca Siwiec, 2009; Czajkowska i Żywiołek, 2011; Dakowicz, 2011a; Dopart, 2018. 
romantyzm w stopniu radykalnym, jego zasób erudycyjny jest wyraźnie modernistyczny i na niego nadkładane są romantyczne kody. Dziedzictwo romantyczne stanowi dla Dakowicza istotny rezerwuar wartości, inklinacje romantyczne dostrzegalne są w każdym zbiorze myśli czy tomiku poezji, lecz myślenie jego jest mocno zakorzenione we współczesności i dosięga go - niestety - przekleństwo pustosłowia.

\section{BibliografiA}

Bauman, Z. (1998). Śmierć i nieśmiertelność. O wielości strategii życia. Warszawa: Wydawnictwo PWN.

Celan, P. (2013). Psalm i inne wiersze. Psalm und andere Gedichte. Wyb. i przeł. R. Krynicki. Kraków: Wydawnictwo A5.

Chateaubriand, F. (1982). Atala. René. Wrocław: Państwowy Instytut Wydawniczy.

Chateaubriand, F. (1991). Pamiętniki zza grobu. Wybór, przekład i komentarz J. Guze. Warszawa: Państwowy Instytut Wydawniczy.

Czajkowska, A. i Żywiołek, A. (red.). (2011). Romantyczne repetycje $i$ powroty. Częstochowa: Wydawnictwo Akademii im. Jana Długosza w Częstochowie.

Dakowicz, P. (2008). Helikon i okolice. Notatki o poezji wspótczesnej. Sopot: Towarzystwo Przyjaciól Sopotu.

Dakowicz, P. (2011a). „Lecz ty spomnisz, wnuku...” Recepcja Norwida w latach 1939-1956. Rzecz o ludziach, ksiazkkach i historii, Warszawa: Instytut Badań Literackich PAN.

Dakowicz, P. (2011b). Place zabaw ostatecznych. Sopot: Towarzystwo Przyjaciół Sopotu.

Dakowicz, P. (2012). Nowoczesność schizofreniczna. Notatki do nienapisanego eseju. Topos, 5(126), 51-60.

Dakowicz, P. (2013). Łaczka. Kraków: Wydawnictwo „Arcana”.

Dakowicz, P. (2014a). Boże klauny. Sopot: Towarzystwo Przyjaciół Sopotu.

Dakowicz, P. (2014b). Obcowanie. Manifesty i eseje. Warszawa: Wydawnictwo Sic!

Dakowicz, P. (2018). Nauka znikania. Wiersze i rozmowy z lat 2006-2018. Warszawa: Wydawnictwo Sic!

Dakowicz, P. (2019). Poezja to bardzo skomplikowany system impulsów... Nowy Napis Co Tydzień, 9.

Dopart, B. (2000). Adam Mickiewicz. W: A. Skoczek (red.), Historia literatury polskiej w dziesięciu tomach, 5, Romantyzm, cz. 1. Bochnia: Prowincjonalna Oficyna Wydawnicza, 271-347. 
Dopart, B. (2018). Komu i do czego służy tradycja romantyczna po roku 1989? W: M. Saganiak i in. (red.), Społeczeństwo polskie dziś. Samoświadomość, uznanie, edukacja. Warszawa: Narodowe Centrum Kultury, 66-87.

Foucault, M. (1987). Historia szaleństwa w dobie klasycyzmu. Warszawa: Państwowy Instytut Wydawniczy.

Foucault, M. (1999). Szaleństwo. Nieobecność dzieła. W: tegoż, Szaleństwo $i$ literatura. Powiedziane, napisane. Wyb. i oprac. T. Komendant, tłum. B. Banasiak i in., posł. M.P. Markowski. Warszawa: Fundacja Aletheia.

Gutting, G. (1989). Michel Foucault's Archeology of Scientific Reason. New York: Cambridge University Press.

Hegel, G.W.F. (2006). Wyktady z filozofii religii. T. 1. Tłum. Ś.F. Nowicki. Warszawa: Wydawnictwo Naukowe PWN.

Heidegger, M. (1995). List o „Humanizmie”. W: tegoż, Znaki drogi. Tłum. S. Blandza i in. Warszawa: Fundacja Aletheia, 129-168.

Henrici, P. (2009). Hegel für Theologen. Gesammelte Aufsätze, Fribourg: Fribourg, Acad. Press.

Horney, K. (1993). Neurotyczna osobowość naszych czasów. Tłum. H. Grzegołowska. Poznań: Dom Wydawniczy Rebis.

Janion, M. (1981). Transgresje: Galernicy wrażliwości. Gdańsk: Wydawnictwo Morskie.

Janion, M. (1982). Odmieńcy. Gdańsk: Wydawnictwo Morskie.

Janion, M. (1984). Osoby. Gdańsk: Wydawnictwo Morskie.

Janion, M. (1986). Maski. Gdańsk: Wydawnictwo Morskie.

Janion, M. (1988). Dzieci. Gdańsk: Wydawnictwo Morskie.

Janoszka, M. i Kalarus, O. (2013). U stóp epoki. W: M. Piechota, M. Janoszka i O. Kalarus (red.), Dziedzictwo romantyczne. O (nie)obecności romantyzmu w kulturze wspótczesnej. Katowice: Wydawnictwo Uniwersytetu Śląskiego w Katowicach, 7-10.

Kapusta, A. (2011). Szaleństwo $i$ metoda: granice rozumienia $w$ filozofii $i$ psychiatrii. Lublin: Wydawnictwo Uniwersytetu Marii Curie-Skłodowskiej.

Kasper, W. (1996). Bóg Jezusa Chrystusa. Wrocław: Wydawnictwo Wrocławskiej Księgarni Archidiecezjalnej.

Kowalczykowa, A. (1977). Romantyczni szaleńcy. Warszawa: Państwowe Wydawnictwo Naukowe.

Kowalczykowa, A. (1978). Ciemne drogi szaleństwa. Kraków: Wydawnictwo Literackie.

Kowalczykowa, A. (1982). Pejzaz romantyczny. Kraków: Wydawnictwo Literackie.

Kubiak, Z. (wyb., oprac. i przeł.). (1993). Twarde dno snu. Tradycja romantyczna w poezji jezyka angielskiego. Blake, Wordsworth, Coleridge, Shelley, Keats, Longfellow, Tennyson, Fitzgerald, Hardy. Kraków: Oficyna Literacka.

Laing, R.D. (1995). Podzielone «ja». Egzystencjalistyczne studium zdrowia i choroby psychicznej. Tłum. M. Karpiński. Poznań: Dom Wydawniczy Rebis. 
Ligęza, W. (2014). Poezja i polski los. Topos, 5 (138).

Lombroso, C. (2015). Geniusz i obtakanie. Tłum. J.L. Popławski. Kraków: Vis-à-Vis/Etiuda.

Mickiewicz, A. (1933). O ludziach rozsądnych i ludziach szalonych. W: tegoż, Dzieta wszystkie. T. 6. Warszawa: Nakładem Skarbu Rzeczypospolitej Polskiej.

Mickiewicz, A. (1981). Świtezianka. W: tegoż, Wiersze. 1829-1855. Oprac. C. Zgorzelski. Wrocław: Wydawnictwo Zakład Narodowy im. Ossolińskich.

Mikołejko, Z. (2001). Kilka słów u umarłej. W: Śmierć i tekst. Sytuacja ostateczna w perspektywie stowa. Gdańsk: Wydawnictwo Słowo/Obraz Terytoria, 15.

Mochnacki, M. (1984). Powstanie narodu polskiego w roku 1830 i 1831. Warszawa: Państwowy Instytut Wydawniczy.

Morawiec, E. (2015). Strażnik poranka. O twórczości Przemysława Dakowicza. Arcana, 1(121).

Muir, J. (1996). Of Men and Numbers. The Story of the Great Mathematicians. New York: Dover Publications.

Nowak, J. (2017). Wytrwata praca straszliwych zuwaczek. Pozyskano z: http:// topoi-miejsca.blogspot.com/2015/06/dr-janusz-nowak-o-bozych-klaunach-p.html (dostęp: 14.02.2017).

Pieczara-Ślarzyńska, M. (2015). Słowa i śmierć. Twórczošć, 8, 125-128.

Piwińska, M. (red.). (2007). Szaleństwo a literatura. Materiaty z konferencji naukowej zorganizowanej przez Fundację na rzecz Badan Literackich w ramach cyklu „Kontynuatorzy czy nowatorzy? Mtodzi badacze i ich warsztaty we wspótczesnych badaniach nad literatura”. „Rocznik Towarzystwa Literackiego im. Adama Mickiewicza”. Warszawa: Wydawnictwo IBL PAN.

Podraza-Kwiatkowska, M. (1969). Bóg, ofiara, clown czy psychopata. O roli artysty na przełomie XIX i XX wieku. Ruch Literacki, 1 (52), 1-17.

Przybyszewski, S. (1996). Confiteor. W: tegoż, Wybór pism. Oprac. R. Taborski. Wrocław: Wydawnictwo Zakład Narodowy im. Ossolińskich.

Pyzia, J. (2018). „Nullum magnum ingenium sine mixtura dementiae fuit”. Romantycy i Przemysław Dakowicz o szaleństwie i poezji. W: J. Pyzia i S. Sarzyńska (red.), O dziennej i nocnej stronie romantycznego podróżowania. Kraków: Księgarnia Akademicka, 25-45.

Robert, M. (2020). Dakowicz o „Teorii wiersza polskiego”. Pozyskano z: https:// www.e-kalejdoskop.pl/literatura-a2 15/dakowicz-o-teorii-wiersza-polskiego-r462 (dostęp: 10.01.2020).

Różewicz, T. (1991). Der Tod ist ein Meister aus Deutschland. W: tegoż, Ptaskorzeźba. Wrocław: Wydawnictwo Dolnośląskie, 272.

Różewicz, T. (2006). Poezja. 3. Wrocław: Wydawnictwo Dolnośląskie.

Ruszar, J. (2019). Mane, tekel, fares: obrazy Boga w twórczości Tadeusza Różewicza. Bielsko-Biała-Kraków: Wydawnictwo Naukowe ATH. 
Siwiec, M. (2009). Romantyzm i zatrzymany czas. Kraków: Wydawnictwo Uniwersytetu Jagiellońskiego.

Sławek, T. (2020). „Gdzie?” Rozwazania oikologiczne. Pozyskano z: https:// depot.ceon.pl/bitstream/handle/123456789/6901/slawek_rozwazania -oikologiczne_anthropos_2011.PDF? sequence $=1$ \&isAllowed $=\mathrm{y}($ dostęp: 10.01.2020).

Słowacki, J. (1983). Dzieła wybrane. Dramaty. T. 5. Wrocław: Ossolineum.

Stabro, S. (2019). Tadeusz Różewicz - los poety w „czasie marnym”. Pozyskano z: https://www.biuroliterackie.pl/biblioteka/ksiazki/powrot-do-rozewicza/ (dostęp: 7.12.2019).

Tan, J., Hope, T. i Steward, A. (2003). Anorexia Nervosa and Personal Identity. The Accounts of Patients and Their Parents. Int. J. Law Psychiatry, 26(5), 533-548.

Tarczyńska, M. (2017). Naturalna neantyzacja nihilizmu. BOŻE KLAUNY. Recenzja. Pozyskano z: http://wpolityce.pl/kultura/251697-naturalna-neantyzacja-nihilizmu-boze-klauny-recenzja (dostęp: 10.01.2020).

Weil, S. (1961). Zakorzenienie. Tłum. A. Wielowieyski. Kraków: Znak.

Zwolińska, B. (2010). Początki romantycznego szaleństwa. W: M. Kasprowicz, S. Drelich i M. Kopyciński (red.), Zjawisko szaleństwa w kulturze. Toruń: Wydawnictwo Uniwersytetu Mikołaja Kopernika, 137-141.

Justyna Pyzia - doktorantka nauk humanistycznych na Wydziale Polonistyki Uniwersytetu Jagiellońskiego. Obecnie pod opieką prof. dra hab. Wojciecha Ligęzy przygotowuje rozprawę doktorską dotyczącą mitu Wielkiej Całości w prozie i publicystyce Józefa Łobodowskiego. Jej licencjat Sakralna perspektywa mitości w kontekście symboliki przestrzeni w poematach: „W Szwajcarii” Juliusza Stowackiego i „Assunta” Cypriana Norwida ukazał się w formie elektronicznej (2013). Redaktorka tomu $O$ dziennej i nocnej stronie romantycznego podróżowania (2018), współredaktorka tomów Czy sq jakieś pytania? Szkice o najnowszej literaturze polskiej (Kraków-Warszawa 2019), Jakże samotny na niepewnej drodze! O ttumaczeniach literatury polskiej (Kraków-Warszawa 2019) oraz Ktusownik i mysliwi. Prywatna historia sztuki Zbigniewa Herberta, Kraków 2020. Autorka szkiców: „Wkraczali we mnie ostro”. Wstyd (Rovigo), w: Gaszcz srebrnych liści. Interpretacje wierszy Zbigniewa Herberta, red. J.M. Ruszar, Kraków 2015, „Nullum magnum ingenium sine mixtura dementiae fuit”. Romantycy i Przemystaw Dakowicz o szaleństwie i poezji, w: O dziennej i nocnej stronie romantycznego podróżowania (2018), Poezja Bogiem przepleciona. Obraz Boga w poezji Juliana Tuwima, w: Obrazy Boga w literaturze polskiej XX i XXI wieku. Od pierwszej do drugiej wojny światowej, red. J.M. Ruszar, D. Siwor, Bielsko-Biała-Kraków 2019. 
